\author{
O.M. Kiselyova*, V.O. Stroieva**, H.V. Stroieva*, A.R. Kosenko** \\ *Oles Honchar Dnipro National University \\ **Dniprovsky State Technical University
}

\title{
NUMERICAL STUDY OF THE PROBLEMS OF OPTIMAL RESOURCE ALLOCATION DURING AN EPIDEMIC
}

In today's global human problem - the COVID-19 pandemic, the optimal resources allocation problem is urgent. Such resources include material, en-ergy, labor, technical, information, financial and others. In turn, resources of each type can be divided into classes. Namely, raw materials can be divided by raw materials types, labor can be divided by professions and qualifica-tions of employees, technical can by technical characteristics, and financial can by sources of funding. The presented problem is devoted to the study of the optimal distribution of resources that correspond to the medical, financial and technical provi-sion of the certain area population.

The numerical research of a number of model problems is carried out for the constructed mathematical model of the problem based on the developed theoretically substantiated algorithms of the decision. The presented research results can serve as a useful tool in terms of effective optimal zoning of existing territorial centers, which are able to produce complexes of population during epidemics and meet the needs of consumers in the field of service at the optimal cost of resources. At the same time, if necessary, it is possible to simultaneously solve the problem of optimal placement of such centers. lem.

Key words: resource allocation, epidemic, optimal division of sets, multiproduct prob-

\section{О.М. Кісельова*, В.О. Стросва**, Г.В. Стросва*, А.Р. Косенко** *Дніпровський національний університет імені Олеся Гончара **Дніпровський державний технічний університет}

\section{ЧИСЕЛЬНЕ ДОСЛІДЖЕННЯ ЗАДАЧ ОПТИМАЛЬНОГО РОЗПОДІЛУ РЕСУРСІВ В УМОВАХ ЕПІДЕМЇ̈}

В умовах сьогоденної глобальної проблеми людства - пандемії COVID-19, актуальною постає задача оптимального розподілу ресурсів. До таких ресурсів можна віднести матеріально-речові, енергетичні, трудові, технічні, інформаційні, фінансові та інші. В свою чергу, ресурси кожного типу можуть бути розподілені на класи. А саме, сировина - за видами сировини, трудові - за професіями та кваліфікаціями працівників, технічні - за технічними характеристиками, фінансові - за джерелами фінансування.

Представлена задача присвячена дослідженню оптимального розподілу ресурсів, які відповідають медичному, фінансовому та технічному забезпеченню населення визначеної території.

Для побудованої математичної моделі задачі, на основі розроблених теоретично обгрунтованих алгоритмів розв'язання, проведено чисельне дослідження ряду модельних задач. Представлені результати досліджень можуть слугувати корисним інструментом у сенсі ефективного оптимального розбиття зон функціонування існую-

(C) Kiselyova O.M., Stroieva V.O., Stroieva H.V., Kosenko A.R., 2020 
чих територіальних центрів, які здатні продукувати комплекси забезпечення населення під час епідемій та задовольняти необхідні потреби споживачів 3 області обслуговування за умов оптимальної вартості відповідних ресурсів. Разом 3 цим, у разі необхідності, можливо одночасно розв'язувати проблему оптимального розміщення таких центрів.

Ключові слова: розподіл ресурсів, епідемія, оптимальне розбиття множин, багатопродуктова задача.

\title{
Е.М. Киселёва*, В.А. Строева**, А.В. Строева*, А.Р. Косенко** *Днипровский национальный университет имени Олеся Гончара **Днипровский государственный технический уиверситет
}

\section{ЧИСЛЕННОЕ ИССЛЕДОВАНИЕ ЗАДАЧ ОПТИМАЛЬНОГО РАСПРЕДЕЛЕНИЯ РЕСУРСОВ ВО ВРЕМЯ ЭПИДЕМИИ}

\begin{abstract}
Проведено численное исследование задач оптимального распределения ресурсов в условиях эпидемии, адаптированных к непрерывным нелинейным задачам оптимального разбиения множеств. Полученные результаты могут быть интересными в смысле их применения во время пандемии.
\end{abstract}

Ключевые слова: распределение ресурсов, эпидемия, оптимальное разбиение множеств, многопродуктовая задача.

Introduction. In today's global human problem - the COVID-19 pandemic, the optimal resources allocation problem is urgent. Such resources include material, energy, labor, technical, information, financial and others. In turn, resources of each type can be divided into classes. Namely, raw materials can be divided by raw materials types, labor can be divided by professions and qualifications of employees, technical can by technical characteristics, and financial can by sources of funding, etc. [1]. The presented problem is devoted to the study of the optimal distribution of resources that correspond to the medical, financial and technical provision of the certain area population.

Statement of the problem. Let's consider some territory on which N centers of territorial provision of the population (CTPP) are located, each of which is charac terized by a set of certain characteristics. For simplicity, we characterize the $i$-th CTPP on the $j$-th type of resources with a certain potential -

$$
\mu_{i}^{j} \in[1 ; \mathrm{k}], \quad i=1, \ldots, N, j=1, \ldots, M, \mathrm{k} \text { - arbitrary natural number. }
$$

It is necessary to divide the set of consumers $\Omega$, which represents the population of a certain area into supply zones with $\Omega_{i}^{j} N$ supply centers separately for each of the $j$-th types of resources (medical, financial and technical) so that

$$
\bigcup_{i=1}^{N} \Omega_{i}^{j}=\Omega, j=1, \ldots, M, \operatorname{mes}\left(\Omega_{i}^{j} \cap \Omega_{k}^{j}\right)=0, i \neq k, i, k=1, \ldots N, j=1, \ldots, M .
$$

It is necessary to minimize the total cost of resources involved:

$$
F\left(\left\{\Omega_{1}^{1}, \ldots, \Omega_{N}^{1} ; \Omega_{1}^{2}, \ldots, \Omega_{N}^{2} ; \ldots ; \Omega_{1}^{M}, \ldots, \Omega_{N}^{M}\right\}\right)=\sum_{j=1}^{M} \sum_{i=1}^{N}\left[\mu_{i}^{j} \varphi_{i}^{j}\left(Y_{i}^{j}\right)+\iint_{\Omega_{i}^{j}} c^{j}\left(x, \tau_{i}\right) \rho^{j}(x, y) d x d y\right],
$$


where $\rho^{j}(x, y)$ is the density with which the demand for the $j$ - th type of resources is distributed in the region $\Omega,(x, y)$ - coordinates of the consumer's location, $\tau_{1}, \ldots, \tau_{N}$ - possible accommodation points of the CTPP, $c^{j}\left((x, y), \tau_{i}\right)-$ distance from consumer to $i$-th CTPP, $\mu_{i}^{j}-i$ - th CTPP potential on the $j$ - th type of services, $\varphi_{i}^{j}\left(Y_{i}^{j}\right)$ - dependence of conditional value $i$ - th CTPP from consumer demand the $j$-th type of resources, where $Y_{i}^{j}=\iint_{\Omega_{i}^{j}} \rho^{j}(x, y) d x d y$ - the power of the $i$-th CTPP the $j$-th type of resources.

At the same time, the capacity of the $i$-th CTPP for all types of resources is determined by the total demand of consumers, which belong to $\Omega_{i}^{j}$ and should not exceed the existing volumes of resources, defined by the relevant restrictions:

$$
\sum_{j=1}^{M} \int_{\Omega_{i}^{j}} \rho^{j}(x) d x=b_{i}, i=1, \ldots, p, \sum_{j=1}^{M} \int_{\Omega_{i}^{j}} \rho^{j}(x) d x \leq b_{i}, i=p+1, \ldots, N .
$$

At the same time the conditions for solving the problem are met:

$$
S=\int_{\Omega} \sum_{j=1}^{M} \rho^{j}(x) d x \leq \sum_{i=1}^{N} b_{i}, \quad 0 \leq b_{i} \leq S, i=1, \ldots, N
$$

The presented problem is a nonlinear continuous multiproduct problem of optimal set division $\Omega \in E^{n}$ on subsets that do not intersect $\Omega_{1}^{1}, \ldots, \Omega_{N}^{1} ; \ldots ; \Omega_{1}^{M}, \ldots, \Omega_{N}^{M}$ with fixed coordinates of the centers of these subsets with constraints in the form of equalities and inequalities.

First, consider the model problems without placing the centers of territorial provision of the population.

Model problem A1. Suppose a set $\Omega=\{(x, y): 0 \leq x \leq 10,0 \leq y \leq 10\}$ of consumers of three types of resources that can be provided by nine centers of territorial provision of the population. The coordinates of finding the consumer $(x, y)$ for the $i$-th

CTPP on the $j$-th type of resources are set according to the type of re-

$$
\text { sources: } c^{j}\left(x, y, \tau_{i}\right)= \begin{cases}\sqrt{\left(x-\tau_{i}^{(1)}\right)^{2}+\left(y-\tau_{i}^{(2)}\right)^{2}}, & j=1 ; \\ \max \left\{\left|x-\tau_{i}^{(1)}\right|,\left|y-\tau_{i}^{(2)}\right|\right\}, & j=2 ; \\ \left|x-\tau_{i}^{(1)}\right|+\left|y-\tau_{i}^{(2)}\right|, & j=3 .\end{cases}
$$

Demand $\rho^{j}(x, y)$ for the $j$-th type of resources is distributed in the area $\Omega$ with the appropriate densities specified in the following analytical form:

$$
\begin{gathered}
\rho^{1}(x, y)=\frac{5}{\ln \left((x-y)^{2}-110.003\right)}, \quad \rho^{2}(x, y)=\frac{0.4}{|\operatorname{tg}| x-y-110.003||}, \\
\rho^{3}(x, y)=\frac{50}{|x-y+110.003|} .
\end{gathered}
$$


The functions $\varphi_{i}^{j}\left(Y_{i}^{j}\right)$, that describe the dependence of the conditional value of the $i$-th CTPP on consumer demand for the $j$-th type of resources, have the form:

$$
\varphi_{i}^{j}\left(Y_{i}^{j}\right)=\left(Y_{i}^{j}\right)^{3}, i=\overline{1,9}, j=1,2,3,
$$

where the power $Y_{i}^{j}$ of the $i$-th CTPP on the $j$-th type of resources, is determined by the formula: $Y_{i}^{j}=\iint_{\Omega_{i}^{j}} \rho^{j}(x, y) d x d y$.

The capacity of the $i$-th CTPP for all types of resources is determined by the total demand of consumers belonging to $\Omega_{i}^{j}, i=\overline{1,9}$, and for CTPP items $i=1,4,5,7,9$ should not exceed the specified volumes, i.e. the following restrictions are imposed on the capacity of CTPP:

$$
\begin{aligned}
& 0 \leq \sum_{j=1}^{3} \iint_{\Omega_{1}^{j}} \rho^{j}(x, y) d x d y \leq b_{i}, i=1,4,5,7,9, \\
& b_{1}=100, b_{4}=10, b_{5}=17, b_{7}=100, b_{9}=25,
\end{aligned}
$$

and for CTPP with numbers $i=2,3,6,8$ should be equal to the specified volumes: $\sum_{j=1}^{3} \iint_{\Omega_{i}^{j}} \rho^{j}(x, y) d x d y=b_{i}, i=2,3,6,8, b_{2}=86, b_{3}=74, b_{6}=25, b_{8}=5$.

It is necessary to divide the set of consumers $\Omega$ into their service areas by nine CTPP for each type of resources, i.e. into subsets $\Omega_{i}^{j}, i=\overline{1,9}, j=\overline{1,3}$, so as to minimize the functionality of the total cost of the resources involved: $\min F\left(\left\{\Omega_{1}^{1}, \ldots, \Omega_{9}^{1} ; \Omega_{1}^{2}, \ldots, \Omega_{9}^{2} ; \Omega_{1}^{3}, \ldots, \Omega_{9}^{3}\right\}\right)=\sum_{j=1}^{3} \sum_{i=1}^{9}\left[\mu_{i}^{j} \varphi_{i}^{j}\left(Y_{i}^{j}\right)+\iint_{\Omega_{i}^{j}} c^{j}\left(x, \tau_{i}\right) \rho^{j}(x, y) d x d y\right]$.

It is no exception that some of the subsets $\Omega_{i}^{j}, i=1,9, j=\overline{1,3}$, will be empty.

The set $\Omega$ was covered with a grid with knots $(i, j), i=1, \ldots, 21, j=1, \ldots, 21$.

As initial values of binary variables $\psi_{i}^{(0)}=0, i=\overline{1,9}$; initial power values: $Y_{1}^{j(0)}=10, \quad Y_{2}^{j(0)}=100, \quad Y_{3}^{j(0)}=10, \quad Y_{4}^{j(0)}=10, \quad Y_{5}^{j(0)}=100, \quad Y_{6}^{j(0)}=10, \quad Y_{7}^{j(0)}=10$, $Y_{8}^{j(0)}=100, Y_{9}^{j(0)}=10, j=\overline{1,3}$; as well as the specified coordinates of the CTPP location:

$$
\tau^{0}=\left(\begin{array}{l}
9.0 ; 6.3 ; 5.1 ; 2.6 ; 7.9 ; 5.5 ; 7.0 ; 9.5 ; 1.8 \\
8.5 ; 7.0 ; 8.9 ; 2.5 ; 2.1 ; 4.5 ; 6.4 ; 5.1 ; 7.7
\end{array}\right)
$$

The condition for the completion of calculations is the execution of the inequality: $\left\|\left(Y^{(k)}, \psi^{(k)}\right)-\left(Y^{(k+1)}, \psi^{(k+1)}\right)\right\| \leq \varepsilon, \quad \varepsilon=10^{-3}$.

For 477 iterations received: 
- optimal division of the set of consumers $\Omega$ :

a)

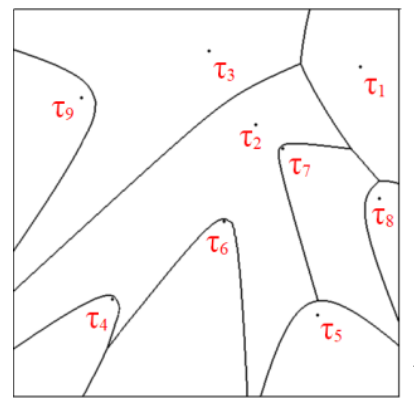

b)

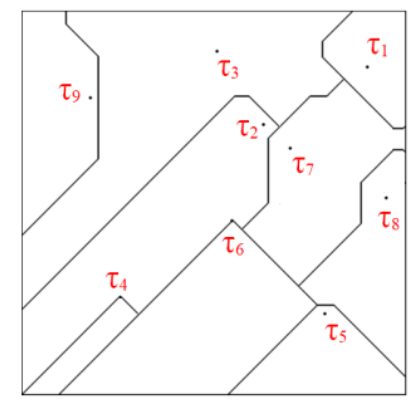

c)

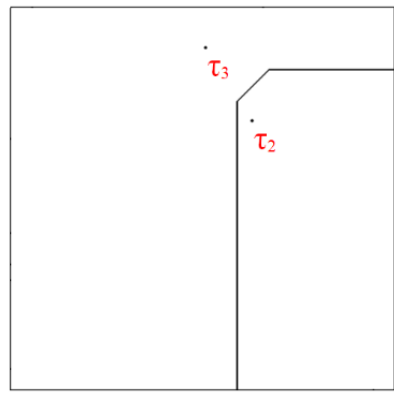

Fig. 1. The optimal division of the set $\Omega$ into service zones by each of the nine CTPP for the three types of resources for model problem A1

- the maximum value of the functionality of the dual problem $G^{*} \approx 129064.1$;

- the minimum value of the functionality of the direct problem $F_{*} \approx 129013.9$

- optimal power of each of the nine CTPP:

$$
\begin{aligned}
& Y_{1}^{1^{*}}=8.5 ; Y_{2}^{1^{*}}=30.47 ; Y_{3}^{1^{*}}=26.79 ; Y_{4}^{1^{*}}=5.01 ; Y_{5}^{1^{*}}=8.54 ; Y_{6}^{1^{*}}=12.54 ; \\
& Y_{7}^{1^{*}}=8.51 ; Y_{8}^{1^{*}}=2.65 ; Y_{9}^{1^{*}}=8.54 \text {; } \\
& Y_{1}^{2^{*}}=8.43 ; Y_{2}^{2^{*}}=30.45 ; Y_{3}^{2^{*}}=26.75 ; Y_{4}^{2^{*}}=4.8 ; Y_{5}^{2^{*}}=8.44 ; Y_{6}^{2^{*}}=12.45 \text {; } \\
& Y_{7}^{2^{*}}=8.41 ; Y_{8}^{2^{*}}=2.2 ; Y_{9}^{2^{*}}=8.4 \text {; } \\
& Y_{1}^{3 *}=0.097 ; Y_{2}^{3 *}=25.08 ; Y_{3}^{3 *}=20.46 ; Y_{4}^{3 *}=0.05 ; Y_{5}^{3 *}=0.03 ; Y_{6}^{3 *}=0.01 \text {; } \\
& Y_{7}^{3^{*}}=0.006 ; Y_{8}^{3^{*}}=0.15 ; Y_{9}^{3^{*}}=0.03 \text {. }
\end{aligned}
$$

Model problem A2. In the formulation of the model problem A1 we set the demand function $\rho^{j}(x, y)=1, j=1,2,3$. Under these conditions, after 461 iterations, the following results were obtained:

- optimal division of the set of consumers $\Omega$ :

a)

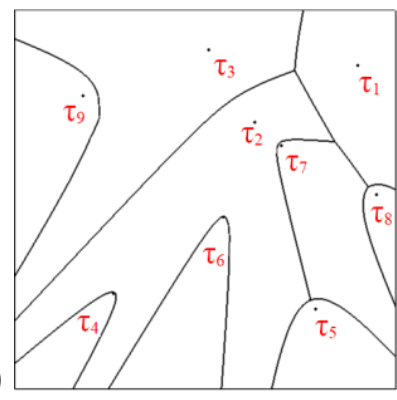

b)

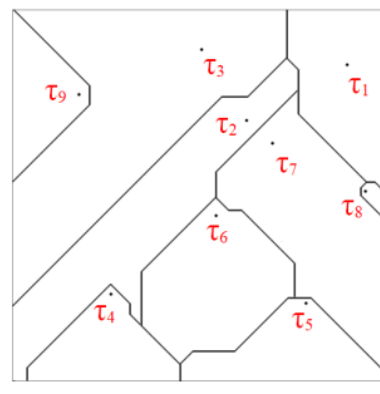

c)

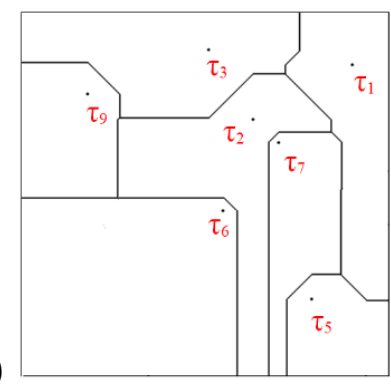

Fig. 2. The optimal division of the set $\Omega$ into service zones by each of the nine CTPP for the three types of resources for model problem $\mathrm{A} 2$

- the maximum value of the functionality of the dual problem $G^{*} \approx 126139.5$;

- the minimum value of the functionality of the direct problem $F_{*} \approx 126128.4$;

- optimal power of each of the nine CTPP: 


$$
\begin{aligned}
& Y_{1}^{1^{*}}=9.72 ; Y_{2}^{1^{*}}=28.53 ; Y_{3}^{1^{*}}=24.67 ; Y_{4}^{1^{*}}=3.35 ; Y_{5}^{1^{*}}=5.64 ; Y_{6}^{1^{*}}=8.35 \text {; } \\
& Y_{7}^{1^{*}}=9.73 ; Y_{8}^{1^{*}}=1.71 ; Y_{9}^{1^{*}}=8.33 \text {; } \\
& Y_{1}^{2^{*}}=9.73 ; Y_{2}^{2^{*}}=28.54 ; Y_{3}^{2^{*}}=24.66 ; Y_{4}^{2^{*}}=3.31 ; Y_{5}^{2^{*}}=5.65 ; Y_{6}^{2^{*}}=8.36 \text {; } \\
& Y_{7}^{2^{*}}=9.74 ; Y_{8}^{2^{*}}=1.56 ; Y_{9}^{2 *}=8.32 ; \\
& Y_{1}^{3^{*}}=9.71 ; Y_{2}^{3^{*}}=28.52 ; Y_{3}^{3^{*}}=24.67 ; Y_{4}^{3^{*}}=3.39 ; Y_{5}^{3^{*}}=5.62 ; Y_{6}^{3^{*}}=8.29 \text {; } \\
& Y_{7}^{3 *}=9.71 ; Y_{8}^{3^{*}}=1.73 ; Y_{9}^{3^{*}}=8.33 \text {. }
\end{aligned}
$$

Now consider the model problems with the location of the centers of territorial provision of the population.

Model problem A3. In the formulation of the model problem A1 we set the condition to place the centers of territorial support of the population. Then, if the initial coordinates of the CTPP placement $\tau_{i}^{(0)}=(0 ; 0), i=\overline{1,9}$, then after 625 iterations we obtain the following result:

- the maximum value of the functionality of the dual problem $G^{*} \approx 128775.2$;

- the minimum value of the functionality of the direct problem $F_{*} \approx 128632.5$;

- optimal coordinates of CTPP locations:

$\tau_{1}^{*}=(5.17 ; 1.44), \quad \tau_{2}^{*}=(7.48 ; 7.44), \tau_{3}^{*}=(2.37 ; 4.29), \tau_{4}^{*}=(4.19 ; 7.87), \tau_{5}^{*}=(1.02 ; 1.001)$, $\tau_{6}^{*}=(8.55 ; 1.52), \tau_{7}^{*}=(1.63 ; 8.74), \quad \tau_{8}^{*}=(8.83 ; 4.14), \tau_{9}^{*}=(5.23 ; 4.88)$;

- optimal power of each of the nine CTPP locations:

$$
\begin{gathered}
Y_{1}^{1^{*}}=8.5 ; Y_{2}^{1^{*}}=30.48 ; Y_{3}^{1^{*}}=26.79 ; Y_{4}^{1^{*}}=5.15 ; Y_{5}^{1^{*}}=8.47 ; Y_{6}^{1^{*}}=12.49 ; \\
Y_{7}^{1^{*}}=8.51 ; Y_{8}^{1^{*}}=2.6 ; Y_{9}^{1^{*}}=8.48 ; \\
Y_{1}^{2^{*}}=8.38 ; Y_{2}^{2^{*}}=30.45 ; Y_{3}^{2^{*}}=26.75 ; Y_{4}^{2^{*}}=4.97 ; Y_{5}^{2^{*}}=8.39 ; Y_{6}^{2^{*}}=12.46 ; \\
Y_{7}^{2^{*}}=8.38 ; Y_{8}^{2^{*}}=2.35 ; Y_{9}^{2^{*}}=8.39 ; \\
Y_{1}^{3^{*}}=0.046 ; Y_{2}^{3^{*}}=25.08 ; Y_{3}^{3 *}=20.46 ; Y_{4}^{3^{*}}=0.14 ; Y_{5}^{3^{*}}=0.027 ; Y_{6}^{3^{*}}=0.05 ; \\
Y_{7}^{3^{*}}=0.11 ; Y_{8}^{3^{*}}=0.05 ; Y_{9}^{3^{*}}=0.12 .
\end{gathered}
$$

- optimal division of the set of consumers $\Omega$ :

a)

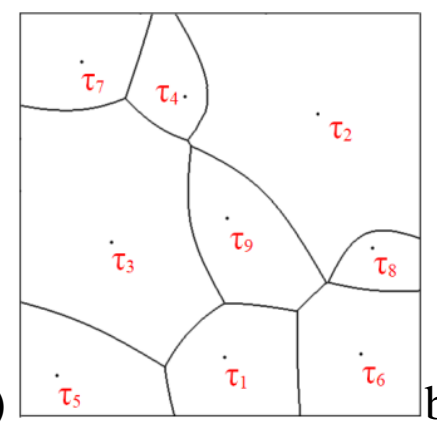

b)

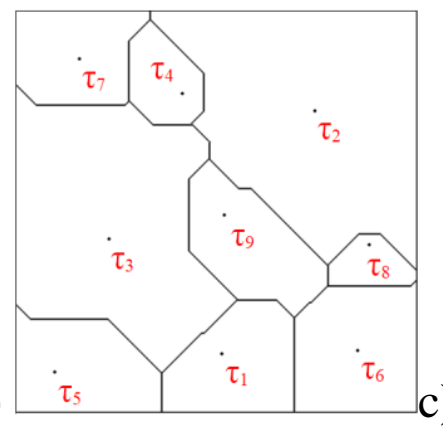

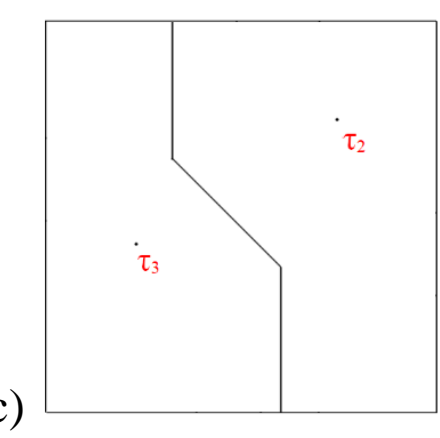

)

Fig. 3. The optimal division of the set $\Omega$ into service zones by each of the nine CTPP for the three types of resources for model problem A3 
Model problem A4. In the formulation of the model problem A3 we set the demand function the same for each type of product, ly $\rho^{j}(x, y)=1, j=1,2,3$, then after 611 iterations we obtain the following results:

- the maximum value of the functionality of the dual problem $G^{*} \approx 125755.7$;

- the minimum value of the functionality of the direct problem $F_{*} \approx 125707.6$;

- optimal coordinates of CTPP locations:

$\tau_{1}^{*}=(7.67 ; 8.68), \tau_{2}^{*}=(2.93 ; 7.53), \tau_{3}^{*}=(2.47 ; 2.51), \tau_{4}^{*}=(6.39 ; 6.27), \tau_{5}^{*}=(6.09 ; 4.03)$, $\tau_{6}^{*}=(6.39 ; 1.32), \tau_{7}^{*}=(8.59 ; 5.48), \tau_{8}^{*}=(9.64 ; 8.22), \tau_{9}^{*}=(8.87 ; 2.001)$;

- optimal division of the set of consumers $\Omega$ :

a)

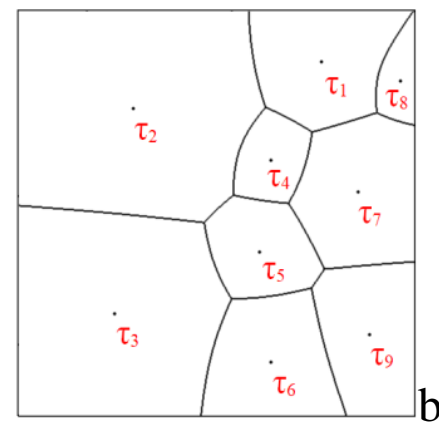

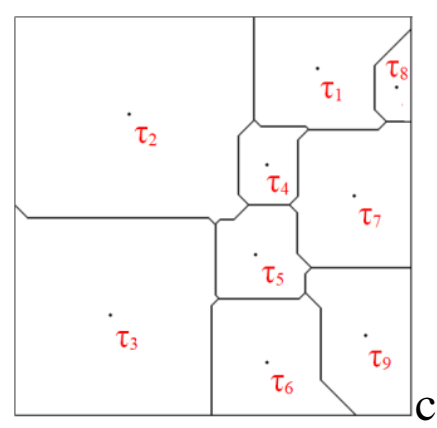

c)

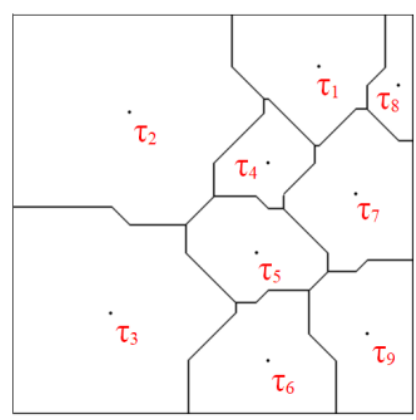

Fig. 4. The optimal division of the set $\Omega$ into service zones by each of the nine CTPP for the three types of resources for model problem A4

- $\quad$ optimal power of each of the nine CTPP locations:

$$
\begin{gathered}
Y_{1}^{1^{*}}=9.66 ; Y_{2}^{1^{*}}=28.66 ; Y_{3}^{1^{*}}=24.67 ; Y_{4}^{1^{*}}=3.43 ; Y_{5}^{1^{*}}=5.64 ; Y_{6}^{1^{*}}=8.35 ; \\
Y_{7}^{1^{*}}=9.66 ; Y_{8}^{1^{*}}=1.6 ; Y_{9}^{1^{*}}=8.35 ; \\
Y_{1}^{2^{*}}=9.66 ; Y_{2}^{2^{*}}=28.66 ; Y_{3}^{2^{*}}=24.67 ; Y_{4}^{2^{*}}=3.43 ; Y_{5}^{2^{*}}=5.64 ; Y_{6}^{2^{*}}=8.37 ; \\
Y_{7}^{2^{*}}=9.66 ; Y_{8}^{2^{*}}=1.75 ; Y_{9}^{2^{*}}=8.35 ; \\
Y_{1}^{3^{*}}=9.66 ; Y_{2}^{3^{*}}=28.65 ; Y_{3}^{3^{*}}=24.66 ; Y_{4}^{3^{*}}=3.43 ; Y_{5}^{3 *}=5.64 ; Y_{6}^{3^{*}}=8.28 ; \\
Y_{7}^{3^{*}}=9.66 ; Y_{8}^{3^{*}}=1.65 ; Y_{9}^{3^{*}}=8.34 .
\end{gathered}
$$

Table 1 shows the general results of the considered model problems.

Thus, in the model problem A1 the demand function $\rho^{j}(x, y) \not \equiv 1, j=\overline{1,3}$, therefore some of the subsets, due to the form of the function $\rho^{j}$, turned out to be empty, which does not contradict the statement of the original problem. For example, in fig. 1, empty are subsets with numbers $1,4,5,6,7,8,9$.

For each of the problems A1-A4 the solvability conditions (1) are satisfied. That is, the total optimal power of nine CTPP, which is obtained by the solution algorithm (for model problem A1 is 267.79, and for model problem A2 is 299.87 , for model problem A3 is 268.073, and for model problem A4 is 300.18) does not exceed $S=442$ - the sum of the specified volumes of CTPP capacity. 
The results of numerical studies of model problems of optimal resource allocation during epidemics

\begin{tabular}{|c|c|c|c|c|c|c|}
\hline \multirow{3}{*}{$\begin{array}{l}\text { Demand for re- } \\
\text { sources }\end{array}$} & \multicolumn{3}{|c|}{ Tasks with CTPP placement } & \multicolumn{3}{|c|}{ Tasks with CTPP placement } \\
\hline & \multirow{2}{*}{$\begin{array}{l}\text { number } \\
\text { of itera- } \\
\text { tions }\end{array}$} & \multicolumn{2}{|c|}{$\begin{array}{c}\text { Optimal values of func- } \\
\text { tionalities }\end{array}$} & \multirow{2}{*}{$\begin{array}{l}\text { number } \\
\text { of itera- } \\
\text { tions }\end{array}$} & \multicolumn{2}{|c|}{$\begin{array}{c}\text { Optimal values of func- } \\
\text { tionalities }\end{array}$} \\
\hline & & $\begin{array}{c}\text { direct, } \\
\boldsymbol{F}_{*}\end{array}$ & $\begin{array}{c}\text { dual, } \\
\boldsymbol{G}^{*}\end{array}$ & & $\begin{array}{c}\text { direct, } \\
\boldsymbol{F}_{*}\end{array}$ & $\begin{array}{c}\text { dual, } \\
\boldsymbol{G}^{*}\end{array}$ \\
\hline \multirow{2}{*}{$\begin{array}{l}\text { Uneven in the } \\
\text { area } \Omega\end{array}$} & \multicolumn{3}{|c|}{ model problem Al } & \multicolumn{3}{|c|}{ model problem $A 3$} \\
\hline & 477 & 129013,9 & 129064,1 & 625 & 128632,5 & 128775,2 \\
\hline \multirow{2}{*}{$\begin{array}{c}\text { Even in the area } \\
\Omega\end{array}$} & \multicolumn{3}{|c|}{ model problem A2 } & \multicolumn{3}{|c|}{ model problem A4 } \\
\hline & 461 & 126128,4 & 126139,5 & 611 & 125707,6 & 125755,7 \\
\hline
\end{tabular}

The obtained optimal powers of the 2nd, 3rd, 6th and 8th CTPP in each of the problems correspond to the constraints in the form of equalities, i.e. are equal to the given value, namely $\sum_{j=1}^{3} Y_{2}^{j^{*}} \approx 86 ; \sum_{j=1}^{3} Y_{3}^{j^{*}} \approx 74 ; \sum_{j=1}^{3} Y_{6}^{j^{*}} \approx 25 ; \sum_{j=1}^{3} Y_{8}^{j^{*}} \approx 5$.

The number of iterations in problems with different demand for resources of each type (model problems A1, A3) is greater than the number of iterations obtained by solving the corresponding problems with the same demand $\rho^{j}(x, y)=1, j=\overline{1,3}$, (model problems A2, A4).

Comparing the optimal values of functionals in model problems $A 1, A 2$ and $A 3$, $A 4$, we have that smaller values of target functionals (i.e. better results) are obtained in the case when the location of CTPP is not fixed, but their placement in area $\Omega$ is allowed.

Conclusions. For the constructed mathematical model of the problem of optimal distribution of resources in the conditions of epidemic on the basis of the developed theoretically substantiated algorithms of the decision from [2] the numerical research of a number of model problems is carried out. The presented research results can serve as a useful tool in terms of effective optimal zoning of existing territorial centers, which are able to produce complexes of population during epidemics and meet the needs of consumers in the field of service at the optimal cost of resources. At the same time, if necessary, it is possible to simultaneously solve the problem of optimal placement of such centers.

\section{References}

1. Kiselyova, O.M. Some problems of optimal distribution of resources [Text] / O.M. Kiselyova, V.O.Stroeva // Mathematical and software of intelligent systems: Abstracts of the XIV International. scientific-practical conf., Oct. 16-18. 2016 - D., DNU, 2016. - P. 91.

2. Kiselyova, E.M. Algorithm for solving a nonlinear continuous multiproduct problem of optimal partitioning of sets with placement of subset centers [Text] / O.M. Kiselyova, V.A. Stroeva // Problems of management and informatics. - 2012. - № 1. - P. 40 - 53.

Received 19.10. 2020. 